\title{
Galactans: An Overview of their Most Important Sourcing and Applications as Natural Polysaccharides
}

\author{
Cedric Delattre $^{1}$, Taratra Andrée Fenoradosoa ${ }^{2,3}$ and Philippe Michaud ${ }^{2 *}$ \\ ${ }^{1}$ Greentech naturally; Biopôle Clermont Limagne 63360 Saint Beauzire - France. ${ }^{2}$ Clermont Université; Université \\ Blaise Pascal; Laboratoire de Génie Chimique et Biochimique; Polytech' BP-10488; F-63000; Clermont-Ferrand- \\ France. ${ }^{3}$ Laboratoire de Chimie des Substances Naturelles (201); Université d'Antsiranana Diego-Suarez - \\ Madagascar
}

\begin{abstract}
Since last decades, lot of biological and rheological properties of polysaccharides and oligosaccharides were described. Among them, galactans and more especially sulfated galactans from seaweeds have shown interesting and specific properties not only as texturing agents but also as biological active compounds on several organisms. This class of polysaccharides includes classical sulfated galactans extracted from seaweeds and classified as agar and carrageenans. However, some galactans are more complex and their specific structural features have been characterized after their extraction from terrestrial plants, seaweeds but also animals and microoragnisms. This review catalogues the origins, structural characteristics and potentialities of these polysaccharides and their oligosaccharides derivatives.
\end{abstract}

Key words: Polysaccharide, seaweed, oligosaccharides, galactan

\section{INTRODUCTION}

Polysaccharides are natural biopolymers isolated from animals, plants, fungi, bacteria but also from seaweeds. The International Union of Biochemistry and Molecular Biology (IUBMB) defined them as macromolecules consisting of a large number of monosaccharide residues joined to each other by glycosidic linkages. They have a large variety of structures and as a consequence, varied biological functions and properties such as: storage of energy (starch, glycogen), cell wall architecture (cellulose, pectins) or gel formation (mucilage). However, they present shared features such as their high density of $-\mathrm{OH}$ functions leading to a hydrophilic character and a high capacity to establish H-bond network. So, except some of them, polysaccharides are generally hydrosoluble and they extensively modify the rheology of aqueous media into which they are introduced, even at low concentrations. This is the basis of their functional properties as thickening and gelling agents. For this, they are actually exploited and valorised, notably in food industries. More, lot of studies have suggested that poly- and oligosaccharides revealed biological functions and were directly implicated in biological responses. So in this context, the identification of new and original polysaccharidic structures constitutes a new field of applications, even if at this time a very low part of natural polysaccharides is exploited. More, the increasing of knowlegdes

*Author for correspondence: Philippe.michaud@univ-bpclermont.fr 
relative to poly- and oligosaccharidic structures with biological functions could help significantly the glycocode decoding. Effectively in an "omic" era, glycomic appears as the next step after genomic and proteomic and the concept of glycome has been validated by glycobiologists (Turnbul and Field, 2007). Polysaccharides can be homopolymers and heteropolymers of neutral (pentoses and hexose) and/or anionic sugars (hexoses), substituted or not by non-sugars compounds, linear, or ramified. A part but not all of them have a regular chemical structure based on 2 up 8 sugars repeat unit. They are stereoregular and may adopt ordered conformation. These features lead to specific behaviours in solution. Resulting conformations are spirals, sheets, single, double and triple helices (Rinaudo, 2004).

To be developed for industrial applications, each new polysaccharidic structure has to find a niche of market unexplored by traditional polysaccharides or their chemical derivates. Therefore, the search for new and/or competitive polysaccharidic agents from natural origins has led to developments in the field of agars, carrageenans and others attractive galactans. All these galactans defined as polymers of galactose, firstly detected in 1892 (Schulze and Steiger, 1892), were isolated from marine and terrestrial ecosystems. They have a lot of applications as stabilizer, viscosifier, gelling and emulsifying agents but only agar and carrageenans have been agreed as food adjuncts.

These sulfated galactans have no equivalent in terrestrial plants and may constitute up to the $70 \%$ of the dry matter of some red seaweeds. At this prospect, these last 2 decades all the research efforts were done to optimize the conditions for their large scale up production from lot of original sources, for their structural investigations and for the characterization of their rheological and biological properties. This review catalogues the last advances in the topic of production of galactan polysaccharides and their potential applications.

\section{GALACTANS FROM SEAWEED}

\section{Generalities}

Many marine algae were characterized by their content in sulfated polysaccharides, which have no equivalent in land plants (Kloareg and Quatrano, 1988). Different classifications were proposed for seaweeds. However, the most useful is based on pigmentation and food reserve. Species employed for extraction of commercial polysaccharide belong to the division Rhodophyta (red algae) and to the division Phaephyta (brown algae). Red algae (Rhodophyta) produced sulfated galactans, agars and carrageenans, which were the main components of their cell walls (Craigie, 1990). Note that other polysaccharides (floridean, cellulose, mannan, xylan and complex extracellular mucilages) were also described for their functions in the cell wall architecture or as food reserve. From more than 4000 red algae (Rhodophyta) species known at present, only about 70-80 species are used for industrial production of gelling galactans. The most important ones belonged to the 2nd subclass (Florideophyceae) of Rhodophyta division, orders Gelidiales and Gigartinales and mainly genera Ahnfeltia, Chondrus, Eucheuma, Furcellaria, Gelidiella, Gelidium, Gigartina, Gracilaria and Pterocladia (Witvrouvw and De Clercq, 1997). Their galactans were abundantly described (Table 1), with a great attention for these of Gracilaria known as a producer of agar (Table 2).

They are made up of linear chains of galactoses and except some of them, their backbone is a linear chain of $\beta$-D-galactopyranose residues linked through positions 1 and 3 (A units) and $\alpha$ D/L-galactopyranose residues linked through positions 1 and 4 (B units) arranged in an alternated sequence $(\mathrm{AB}) n$ (Fig. 1). They can be ramified by other neutral sugars (Xyl, Glc, Ara, Man), can carry methyl ether groups, sulfate hemiester groups and pyruvic acid linked as a cyclic ketal. Some of these galactans have their B units totally or partially replaced with 3,6anhydro-L/D-galactopyranose after elimination of sulfate from C6 by enzymatic or alkalin treatment. In relation with all these structural features, sulfated galactans from seaweeds are classified in three classes: agarocolloides, carrageenans and complex galactans.

\section{The agarocolloids}

The agarocolloids have been divided into two groups: agars and agaroids (Craigie, 1990). The main difference between them lies in the fact that among agars, the part of 4- $\alpha$-D-galactopyranose (B unit) in the form of derived 3,6-L/Danhydrogalactose is very high and the percentage of sulfate groups are weaker (around 2\%) than among agaroids (20\%). 
Table 1 - Main red algae producers of galactans.

\begin{tabular}{lccccl}
\hline Sources & Sugar units & Substitutions & Linkages & Yield & References \\
\hline Callophyllis variegata & D-Gal, D-AnGal Xyl, Glc & Sul & $\beta-(1,4) \alpha-(1,3)$ & $16.3 \%$ & Rodriguez et al., 2005 \\
$\begin{array}{l}\text { Phacelocarpus } \\
\text { peperocarpos }\end{array}$ & D-Gal, D-AnGal Xyl, Glc & Sul & $\beta-(1,4) \alpha-(1,3)$ & $24-45 \%$ & Liao et al., 1996 \\
Eucheuma denticulatum & D-Gal, D-AnGal & Sul & $\beta-(1,4) \alpha-(1,3)$ & $24 \%$ & Viana et al., 2004 \\
Schizymenia binderi & D-Gal, Glc, Xyl & Pyr, Sul & $\alpha-(1,3) \beta-(1,4)$ & $17.6 \%$ & Matsuhiro et al., 2005 \\
Claviclonium ovatum & Gal, Glc, Xyl & Met, Sul & - & $32 \%$ & Chiovitti et al., 2004 \\
Sarconema filiforme & Gal, Xyl, Ara Man, Glc & - & - & $6-13 \%$ & Chiovitti et al., 1998 \\
Ahnfeltia tobuchiensis & Gal, An-Gal & Met, Sul & - & - & Truus et al., 2006 \\
Grateloupia indica & Gal, Glc, Xyl, Fuc & Sul, Pyr & $\alpha-(1,3) \beta-(1,4)$ & $13 \%$ & Chattopadhyay et al, \\
$\begin{array}{l}\text { Bostrychia montagnei } \\
\text { Pachymenia lusoria }\end{array}$ & D-Gal, L-Gal, AnGal, Xyl & - & $\alpha-(1,3) \beta-(1,4)$ & - & Duarte et al., 2002 \\
$\begin{array}{l}\text { Codium yezoense } \\
\text { Gymnogongrus }\end{array}$ & D-Gal, L-Gal, AnGal, Xyl & Sul, Met, Pyr & $\alpha-(1,3) \beta-(1,4)$ & - & Miller et al., 1995 \\
torulosus & D-Gal, Arab, Xyl & Sul, Pyr & $\beta-(1,6), \alpha-(1,3)$ & - & Bilan et al., 2007 \\
\hline
\end{tabular}

Table 2 - Gracilaria agar producers.

\begin{tabular}{|c|c|c|c|c|c|}
\hline Species & Sugar units & Linkages & Substitution & Yield & References \\
\hline Gracilaria edulis & $\begin{array}{l}\text { D-Gal, L-Gal, } \\
\text { AnGal }\end{array}$ & $\beta-(1,3) \alpha-(1,4)$ & Sul & - & $\begin{array}{l}\text { Villanueva } \\
\text { et al., } 1999\end{array}$ \\
\hline Gracilaria salicornia & $\begin{array}{l}\text { D-Gal, L-Gal, } \\
\text { AnGal }\end{array}$ & $\beta-(1,3) \alpha-(1,4)$ & Sul & $2.9+/-0.1 \%-15.7+/-1.3 \%$ & $\begin{array}{l}\text { Calumpong } \\
\text { et al., } 1999\end{array}$ \\
\hline Gracilaria arcuata & $\begin{array}{l}\text { D-Gal, L-Gal, } \\
\text { AnGal }\end{array}$ & $\beta-(1,3) \alpha-(1,4)$ & Sul & $2.9+/-7 \%-21.7+/-0.7 \%$ & $\begin{array}{l}\text { Calumpong } \\
\text { et al., } 1999\end{array}$ \\
\hline Gracilaria blodgettii & $\begin{array}{l}\text { D-Gal, L-Gal, } \\
\text { AnGal }\end{array}$ & $\beta-(1,3) \alpha-(1,4)$ & Sul & $20.7+/-5.9 \%$ & $\begin{array}{l}\text { Calumpong } \\
\text { et al.,1999 }\end{array}$ \\
\hline Gracilaria cornea & $\begin{array}{c}\text { D-Gal, L-Gal, } \\
\text { AnGal }\end{array}$ & $\beta-(1,3) \alpha-(1,4)$ & Sul & $20.1+/-1.5 \%$ & $\begin{array}{l}\text { Freile- } \\
\text { Pelegrim, } 2000\end{array}$ \\
\hline Gracilaria sp & $\begin{array}{c}\text { D-Gal, L-Gal, } \\
\text { AnGal }\end{array}$ & $\beta-(1,3) \alpha-(1,4)$ & Sul & - & $\begin{array}{l}\text { Friedlander } \\
\text { et al.,1984 }\end{array}$ \\
\hline
\end{tabular}

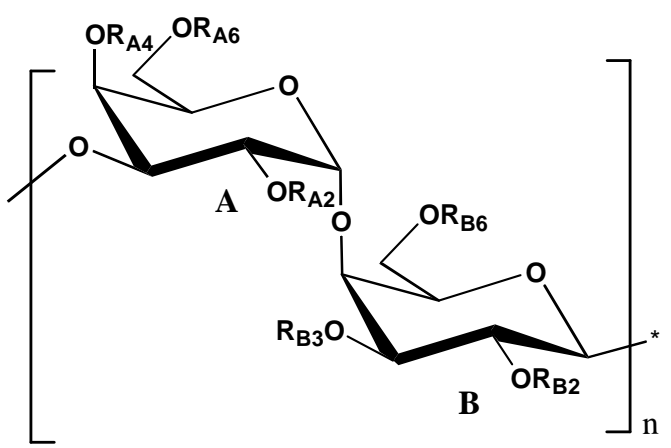

Figure 1 - Schematic and global representation of sulfated galactans from red seaweeds. B unit is in D configuration. $\mathrm{R}_{\mathrm{A} 2}: \mathrm{H}, \mathrm{SO}_{3}{ }^{-} ; \mathrm{R}_{\mathrm{A} 4}: \mathrm{H}, \mathrm{SO}_{3}{ }^{-}$; Pyruvic acid (cyclic ketal with $0_{6}$ ); $\mathrm{R}_{\mathrm{A} 6}$ : $\mathrm{H}, \mathrm{CH}_{3}, \mathrm{SO}_{3}{ }^{-}$; Pyruvic acid (cyclic ketal with $0_{4}$ ), $\mathrm{R}_{\mathrm{B} 2}: \mathrm{H}, \mathrm{CH}_{3}, \mathrm{SO}_{3}{ }^{-} ; \mathrm{R}_{\mathrm{B} 3}: \mathrm{H}, \mathrm{R}_{\mathrm{A} 6}: \mathrm{H}$, $\mathrm{SO}_{3}{ }^{-}$.

\section{Agar}

Agar, currently known as "agar-agar", a Malaysian name for seaweeds, was extracted from red seaweeds belonging to Gelidium, Pterocladia, Petrocladiella, Gracilaria and Hypnea species (Rinaudo, 2007). Structurally, agar is made up of a 
complex series of polysaccharides going from a neutral one, the agarose, to a highly charged galactan: the agaropectin. Agarose (sometimes called agaran) is a linear polymer with the $A B$ alterning sequence called agarobiose where the $\mathrm{B}$ unit is 3,6- $\alpha$-L-anhydrogalactopyranose (Fig. 2). This polymer with a molecular weight of 120000 Da has low sulfatation degrees (about 2\%) but the C6 of the A unit may be highly methylated (up to $20 \%$ ). The major differences between agarose and carrageenans was described as the presence of 3,6$\alpha$-L-anhydrogalactopyranose rather than 3,6- $\alpha$-Danhydrogalactopyranose and the lack of sulfate groups (Rees, 1969). Agaropectin is a heterogeneous mixture of smaller molecules that occur in lesser amounts. They were structurally characterized by the same backbone that agarose with many acid groups such as sulfate, pyruvate but also glycuronate (Furneaux and Stevenson, 1990; Knutsen et al., 1994). Agaropectin were also methylated (Akari, 1996; Rinaudo, 2007).

Agar and agarose are not soluble in water at room temperature and they are abundantly exploited for their gelling properties. Agar is extracted from red algae in boiling water with or without alkali leading to polysaccharides with various rates of 3,6- $\alpha$-L-anhydrogalactopyranose.

After its solubilisation in hot water $\left(85\right.$ to $\left.100{ }^{\circ} \mathrm{C}\right)$, agar solidifies in the range from 30 to $40^{\circ} \mathrm{C}$. Gelation of agar involves conversion from a fluctuating disordered coil conformation in water solution to a rigid ordered structure (co-axial double helix) which forms the junction zones of the gel network. Agarose gives the stronger gels.

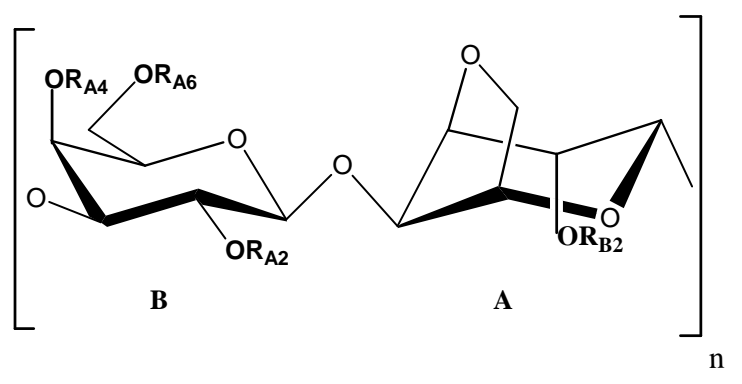

Figure 2 - Schematic representation of agarobiose and agaropectin. $\mathrm{R}_{\mathrm{A} 2}: \mathrm{H}, \mathrm{SO}_{3}^{-} ; \mathrm{R}_{\mathrm{A} 4}: \mathrm{H}, \mathrm{SO}_{3}^{-}$; Pyruvic acid (cyclic ketal with $0_{6}$ ); $\mathrm{R}_{\mathrm{A} 6}: \mathrm{H}, \mathrm{CH}_{3}, \mathrm{SO}_{3}^{-}$; Pyruvic acid (cyclic ketal with $\left.0_{4}\right), \mathrm{R}_{\mathrm{B} 2}: \mathrm{H}, \mathrm{CH}_{3}, \mathrm{SO}_{3}^{-}$.

\section{The agaroids}

The agaroids polysaccharides are close to the ideal structure of agarobiose (Fig. 2), but they include fewer units of 3,6-anhydrogalactose, replaced by $4-\alpha$-L-galactopyranose. The rate of their sulfate groups can reach up to $20 \%$ generally placed on C6 of $\alpha$-L-galactopyranose. Among these agaroids two examples can be cited: (i) that of funorans whose proposal A and B units are, as for agars, Dgalactose and 3,6-L-anhydrogalactose, but whose C6 and C2 hydroxyl of 3- $\beta$-D-galactopyranose and
4- $\alpha$-L-galactopyranose are substituted by sulfates or methyl groups (Fig. 3); (ii) that of porphyrans, produced by Porphyra umbilicalis. Porphyran is a highly substituted agarose-type. It was described as constituted of 4-linked 6-O-sulfo- $\alpha$-Lgalactopyranose (the precursor of the 3,6- anhydro unit) and 3-linked 6-O-methyl- $\beta$-Dgalactopyranose (Fig. 4) (Morrice et al., 1983). Note that funoran extracted from the kind Gloiopeltis was used as adhesive (Hirase and Watanabe, 1972).

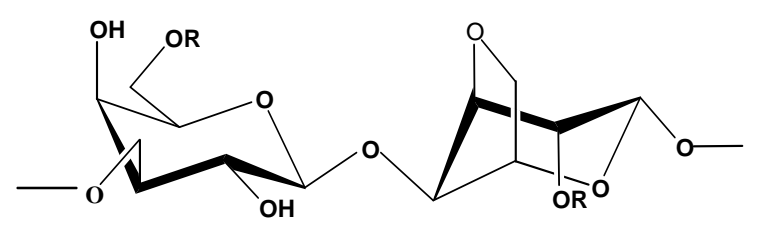

Figure 3 - Structure of furonan $\mathrm{R}: \mathrm{CH}_{3} ; \mathrm{SO}_{3}{ }^{-}$. 


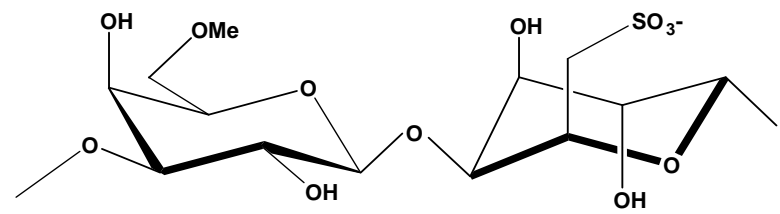

Figure 4 - Structure of porphyran.

\section{CARRAGEENANS}

\section{Kappa and Lambda families}

Carrageenans are linear galactans with D-galactose residues $\alpha-(1,4)$ and $\beta-(1,3)$ linked alternately. In this repeating unit called carrabiose the galactose residues $\alpha$ - $(1,4)$ linked (A unit) often occur as 3,6anhydro-D-galactose (Fig. 5). Sulfate ester groups were found on some or all galactoses (Knutsen et al., 1994; Rees, 1969). It is evident that since carrageenan is a large molecule being made up of some 1000 residues, the possibility for structural variations is enormous. The carrageenans have been categorized in several families and subfamilies according to the number and position of sulfate ester, rate of $(3,6)$ anhydro-bridges in the $\alpha$-related residues and on their solubility in solutions of potassium chloride (Smith and Cook, 1953). They were characterized as high molecular weight polysaccharides with $20 \%$ to $40 \%$ sulfateester content (Kloareg and Quatrano, 1988).
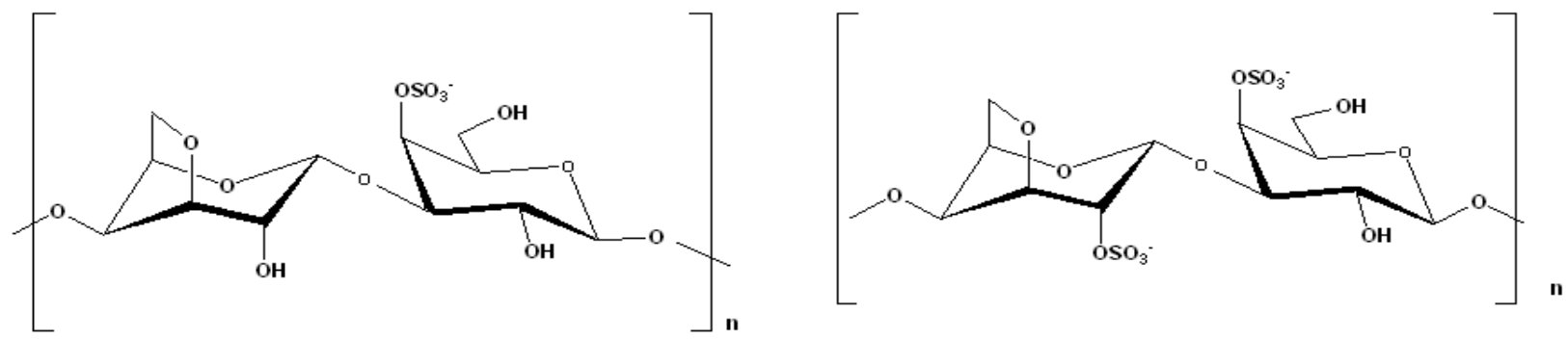

A: kappa-carrabiose

B: Iota-carrabiose

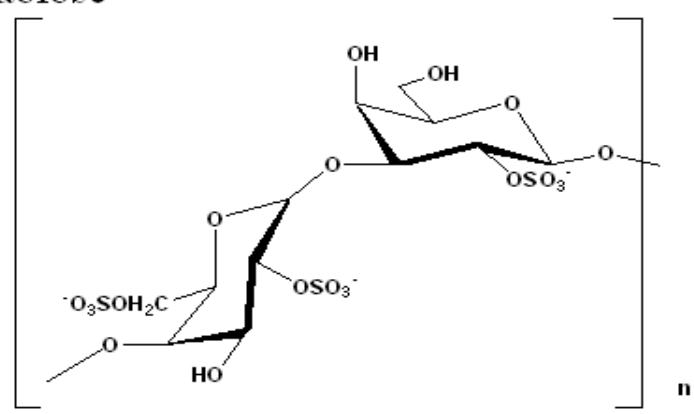

C: Lambda-carrabiose

Figure 5 - Schematic representations of carrabioses.

Higher levels of sulfate ester meant higher level of solubility and lower gel strength. The first group forming gels has been defined as Kappa family and included iota ( $\mathrm{l}$ ) and kappa ( $\kappa)$ carrageenans as well as their precursors: the $X(\mu)$ and $Y(v)$ carrageenans respectively (Anderson et al., 1973). All the members of this family were sulfated in C4 position of the $\mathrm{A}$ unit. The main differences between the $\kappa$ and 1 subfamilies were a $\mathrm{C} 2$ sulfated $B$ unit in the case of 1 and an higher 3,6anhydrogalactose content $(28-35 \%)$ for $\kappa$ carrageenans compared to $l$ one $(25-30 \%)$. The precursors forms of $\kappa(\mu)$ and $\imath(v)$ subfamilies had the same features except the presence of 3,6anhydrogalactose residues replaced by a 6-Osulfated B unit. The second family, called $\lambda$ 
carrageenans is not sulfated at $\mathrm{C} 4$ position of the $\mathrm{B}$ unit and without 3,6-anhydrogalactopyranose. It is the most sulfated carrageenan with 3 sulfate groups per repeating unit. These ester sulfates are located on $\mathrm{C} 2$ of $\mathrm{A}$ unit and in $\mathrm{C} 2$ and $\mathrm{C} 6$ of $\mathrm{B}$ units. This polysaccharide with highly anionic load owned thickening properties but not gelling ones (Rees, 1969; Greer and Yaphe, 1984). The $\lambda$ family contains subfamilies including xi $(\xi)$, theta $(\theta)$ and pi $(\pi)$-carrageenans, where only the $4-\alpha-D-$ galactopyranose unit varies (Fig. 6). The theta structure has a B unit only sulfated at C2 position.
It was obtained by slow alkaline transformation of the lambda carrageenan (Ciancia et al., 1993). This structure was also detected naturally present in some algae such as Callophyllis hambroniana (Miller, 2003; Falshaw et al., 2005).

The other structures of this family as desulfated $\xi$ carrageenan (Penman and Rees, 1973) and pyruvated $\pi$ carrageenan (DiNinno et al., 1979) have been observed in tetrasporophytes from different species of Gigartinaceae (McCandless et al., 1983; Falshaw and Furneaux, 1995; Falshaw and Furneaux, 1998).

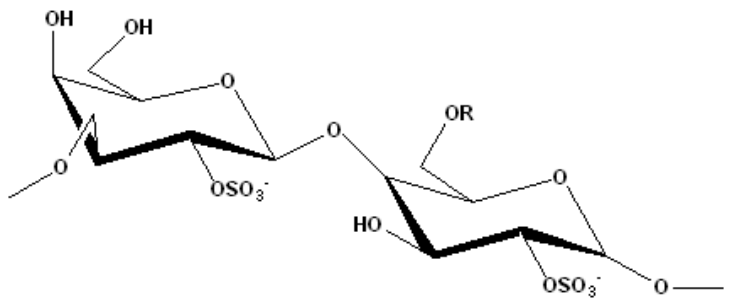

$\mathrm{R}=\mathrm{H}$ (A) xi-carrageenan $\mathrm{R}=\mathrm{SO}_{3}{ }^{-}$lambda-carrageenan

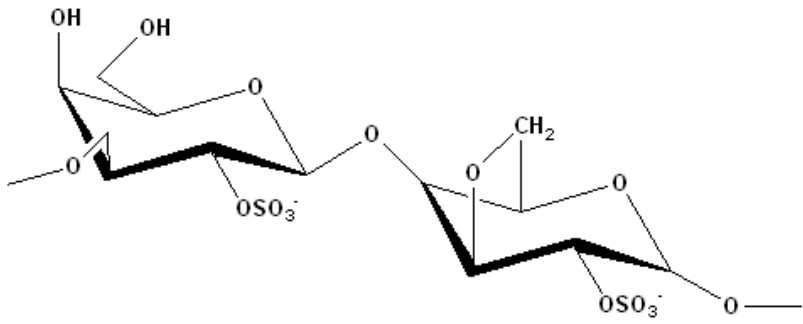

(B) Théta-carrageenan

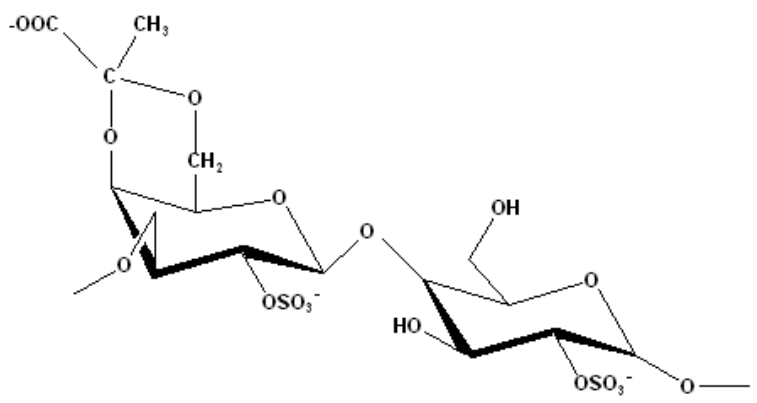

(C) pi-carrageenan

Figure 6 - Schematic representation of lambda-carrageenans. (A): xi-carrageenan, (B): thetacarrageenan, (C): pi-carrageenan

\section{Carrageenan hybrids.}

Each carrageenan extracted from algae could be considered as a hybrid, comprising a regular sequence of the same diholoside interrupted by segments of another type of carrageenan (Bellion et al., 1982). It was sometimes difficult to estimate whether a polysaccharide is a single molecule or a hybrid of two distinct carrageenans (Craigie, 1990). It is also interesting to note that in general, the nature of carrageenan produced by algae depends on the different generations of biological cycle. For example, the species belonging to Gigartinales order may contain several types of carrageenans and in one case, the structural variability associated with the alternation of generations especially considering levels of sulfate groups and 3,6-anhydrogalactoses, has been highlighted. McCandless et al. (1982, 1983) have studied the carrageenans of Phyllophoraceae and Gigartinaceae and have shown that the parietal polysaccharides generated by gametophyte were a hybrid form of $\mathrm{l} / \kappa$ or $\kappa / \mathrm{l}$ depending on the species, while carrageenan from tetrasporophyte were rather $\lambda$ subfamilies forms $(\lambda, \xi$ and $\pi)$. This trend was confirmed since some types of Gigartinaceae such as Chondrus, Gigartina, Iridea or 
Rhodoglossum were gametophytes producing $\mathrm{K}$ or 1 carrageenan, while their tetrasporophytes contained $\lambda$ or $\xi$ types (Chen and McLachlan, 1972; Matsuhiro and Urzua, 1992; Matulewicz et al., 1989; 1990; McCandless and Craigie, 1974; McCandless et al., 1973, 1983; Pickmere et al.,
1973). More recently, Falshaw et al. (2001) have also demonstrated for the Chilean red algae Sarcothalia crispata and Gigartina skottsbergii the presence of hybrid carrageenans. The various species which produce the hybrid carrageenans are summaries in Table 3.

Table 3 - Carrageenan hybrid producers.

\begin{tabular}{lccl}
\hline & \multicolumn{4}{l}{ Carrageenan type following the biologic cycle } \\
\hline Species & Gametophyte & Tetrasporophyte & References \\
\hline Gigartina skottsbergii & $\kappa$ and $\mathrm{l}$ or $(\mu$ and $v)$ & $\lambda$ & Falshaw et al., 2001 \\
Sarcothalia crispata & $\kappa$ and $\mathrm{or}(\mu$ and $v)$ & $\lambda$ & Falshaw et al., 2001 \\
Gigartina atropurpurea & $\kappa$ and $\mathrm{or}(\mu$ and $v)$ & $\lambda$ & Falshaw et al., 2003 \\
Gigartina clavifera & $\kappa$ and $\mathrm{r}$ & $\xi$ & Falshaw et al., 1995 \\
Gigartina alveata & $\kappa$ and $\mathrm{l}$ & $\xi$ & Falshaw et al., 1995 \\
Gigartina pistillata & $\kappa, \mathrm{l}$ and $v$ & $\lambda, \xi$ and $\pi$ & Falshaw, et al., 1998 \\
\hline
\end{tabular}

\section{COMPLEX GALACTANS}

Can be classified as "complex galactans" linear backbone of galactoses arranged with the previous described alterning sequence $\mathrm{AB}$ and ramified by other hexoses and/or pentoses. Complex galactans have been extracted, purified ans characterized from the red alga Halymeniales (or Cryptonemiales) families such as: Grateloupia elliptica, Pachymenia carnosa and Pachymenia lusoria (Hirase et al., 1967, Farrant et al., 1972; Miller et al., 1995). Apart the Halymeniales family, certain genus of other families of red alga contained complex galactans such as Asparagopsis armata (Garon-Lardiere, 2004). A highly complex structure has been also isolated from Kappaphycus alvarezii (Estevez et al., 2000). In this case, the polysaccharide contained $\mathrm{D}$ and $\mathrm{L}$ galactopyranoses as B units and was ramified by galactose, glucose and xylose linked to $\mathrm{C} 2$ and/or
$\mathrm{C} 4$ of the 3-linked $\beta$-D-galactose units and $\mathrm{C} 3$ and/or $\mathrm{C} 2$ of the 4-linked $\alpha$-D- and/or $\alpha$-Lgalactose residues (Estevez et al., 2000). The second well documented complex galactan was the sulfated, pyruvilated and methylated polysaccharide from the red algae Pachymenia Lusoria. Its structural analysis showed a backbone of 3-1inked D-galactopyranoses alternating with 4linked D- or L-galactopyranosyl residues. The 3linked residues were nearly all 2-O-sulfated. Considering this A unit, it was 6-O-methylated and 4,6 pyruvylated all the 3 and 6 residues respectively. Analysis of 4-1inked galactopyranoses revealed that half were 2-Omethylated. The rest of them were galactopyranosyl residues in D (50\%) and L (50\%) configurations (Miller et al., 1995). Other structures of complex galactans were summarized in the Table 4.

Table 4 - Structures of complex galactans.

\begin{tabular}{|c|c|c|c|c|c|}
\hline Species & $\begin{array}{c}\text { Gal } \\
\text { Configuration }\end{array}$ & Structure & $\begin{array}{c}\text { Substituent } \\
\text { monosaccharide }\end{array}$ & $\begin{array}{l}\text { Substituent } \\
\text { group }\end{array}$ & References \\
\hline $\begin{array}{l}\text { Cryptonemia } \\
\text { crenulata }\end{array}$ & DL-hydrid & $\begin{array}{l}\text { 3)- } \beta \text {-D-Galp-(1,4)- } \alpha- \\
\text { Galp- }(1,\end{array}$ & $\begin{array}{c}\beta-\mathrm{D}-\mathrm{Xyl}, \beta-\mathrm{D}- \\
\text { Gal }\end{array}$ & Sul Met Pyr & $\begin{array}{l}\text { Zibetti et al., } \\
2005\end{array}$ \\
\hline $\begin{array}{l}\text { Kappaphycus } \\
\text { alvarezii }\end{array}$ & DL-hydrid & $\begin{array}{c}\text { 3)- } \beta \text {-D-Galp- }(1,4)-\alpha- \\
\text { Galp- }(1,\end{array}$ & $\begin{array}{l}\beta-\mathrm{D}-\mathrm{Xyl}, \beta-\mathrm{D}- \\
\text { Glu }\end{array}$ & Sul Met & $\begin{array}{l}\text { Estevez et al., } \\
2004\end{array}$ \\
\hline $\begin{array}{l}\text { Porphyra } \\
\text { columbina }\end{array}$ & DL-hydrid & $\begin{array}{c}\text { 3)- } \beta \text {-D-Galp- }(1,4)-\alpha- \\
\text { Galp- }(1,\end{array}$ & & Sul Met & $\begin{array}{l}\text { Brasch et al., } \\
1981\end{array}$ \\
\hline $\begin{array}{l}\text { Gymnogongrus } \\
\text { torulosus }\end{array}$ & DL-hydrid & $\begin{array}{c}\text { 3)- } \beta \text {-D-Galp-(1,4)- } \alpha \text { - } \\
\text { AnGalp- }(1,\end{array}$ & $\beta-\mathrm{D}-\mathrm{Xyl}$ & Sul & $\begin{array}{l}\text { Estevez et al., } \\
2008\end{array}$ \\
\hline $\begin{array}{l}\text { Gloiopeltis } \\
\text { furcata }\end{array}$ & DL-hydrid & $\begin{array}{l}\text { 3)- } \beta \text {-D-Galp- }(1,4)-\alpha- \\
\text { Galp- }(1,\end{array}$ & & Sul Met & $\begin{array}{l}\text { Takano et al., } \\
1998\end{array}$ \\
\hline $\begin{array}{l}\text { Grateloupia } \\
\text { indica: }\end{array}$ & $\mathrm{D}$ & $\begin{array}{l}\text { 3)- } \alpha \text {-D-Galp- }(1,4)-\alpha- \\
\text { Galp- }(1,\end{array}$ & $\begin{array}{l}\text { Fuc, } \\
\text { Xylu, Gal, }\end{array}$ & Sul & $\begin{array}{l}\text { Chattopadhyay } \\
\text { et al., } 2007\end{array}$ \\
\hline $\begin{array}{l}\text { Pachymenia } \\
\text { lusoria }\end{array}$ & DL-hydrid & $\begin{array}{l}\text { 3)- } \beta \text {-D-Galp-(1,4)- } \alpha \text { - } \\
\text { Galp- }(1,\end{array}$ & Xyl & Sul Met Pyr & $\begin{array}{l}\text { Miller et al., } \\
1995\end{array}$ \\
\hline
\end{tabular}




\section{Physico-chemical properties of seaweed galactans}

The sulfated galactans such as agarose or carrageenans are extensively exploited imputable their industrial applications. These biopolymers are considered as the major hydrocolloids used as texturing agents for food industrial application. The wide employments of these marine sulfated polysaccharides are essentially based on their unique properties to form strong aqueous gels (Ress et al., 1982; Lahaye, 2001). It was well known that modifications in the backbone of sulfated galactans allowed to greatly changes in their physico-chemical and biological properties (Lahaye, 2001). For example, just a small conformation/configuration change from $\alpha$-Dgalactopyranoses in carrageenans to $\alpha$-Lgalactopyranoses in agaran could promote very important modifications in these polysaccharides (Lahaye, 2001). Moreover, it was largely defined that a higher levels of 3,6-anhydro- $\alpha$-Lgalactopyranosyl units in agarans and a lower sulfate contents were the major structural requirements for gelling (Lahaye, 2001).

In gelling applications, agarose, $\kappa-$, and $1-$ carrageenans form thermoreversible gels in aqueous solutions. Agar is known to form a very porous gel and the pore size can be roughly measured by assessing the size of particulates that are excluded from the gel in a gel permeation experiment. It has been shown that agar gels could allow to molecules up to 30000 daltons to percolate through their gelling network. An agar gel has the unusual property of behaving like a sponge. It can be dried and upon rehydration it will swell to its original size and shape (Ress et al.,
1982). The carrageenan would cause excessive flocculation due to the protein reactivity. The reactivity with proteins depends on gelling properties of carragenans but also on their structural regularity. In most, cases ion-ion interactions between the sulfate groups of polysaccharides and the cationic character of protein are involved. For this, in food systems, one of the most important properties that truly differentiate carrageenan ( $l$ and $\kappa$ ) from other hydrocolloids is its ability to complex or interacts with proteins. In milk protein systems, at peripheral locations on the casein micelle there is a concentration of positive charges attracting the negatively-charged sulfate groups of carrageenans to form linkages among the dispersed casein micelles (Fig. 7). This reaction, in combination with the normal water gelling capabilities of carrageenan, can increase the gel strength about 10 -fold. Thus, cationic groups allowed to determine the physical properties of carrageenans as $\kappa$ - and $\mathrm{l}$ - but not $\lambda$-carrageenans formed gels in presence of potassium or calcium ions (Morris et al., 1980; Rees et al., 1982).

As well described for many years, gelling in carrageenan is caused by helix formation occurring in repeat structures where the $\mathrm{B}$ residue is in a ${ }^{1} \mathrm{C}_{4}$ conformation. Lambda carrageenan with its two sugar residues in a ${ }^{4} \mathrm{C}_{1}$ conformation and does not form gels. All the gelling types of carrageenan which include $\kappa, \beta$ and 1 contain a 3,6 anhydro bridge on the $\mathrm{B}$ unit which forces the sugar to flip from a ${ }^{4} \mathrm{C}_{1}$ conformation to a ${ }^{1} \mathrm{C}_{4}$ one forming then cross-link networks and gels (Morris et al., 1980; Rees et al., 1982).

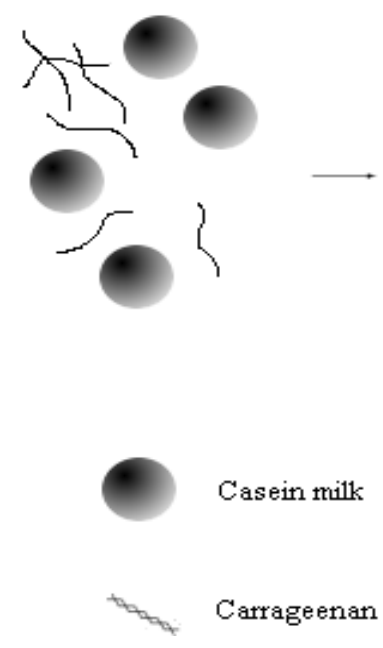

Figure 7 - Interaction of milk protein with carrageenan. 


\section{GALACTANS FROM PLANTS}

It was well defined that plants could store a very large number of carbohydrate polymers. Starch is the principal polysaccharide, followed by fructans and cell wall storage polysaccharides defined as CWSP (McCann and Roberts, 1991; Carpita and Gibeaut, 1993). As mentioned in the plant cell wall model, it was shown that CWSP were mainly present in seeds (Reid, 1985; McCann and Roberts, 1991; Carpita and Gibeaut, 1993). Therefore, a classification in CWSPs revealed 3 polysaccharide families: mannans, xyloglucans and galactans (Table 5). The later were mainly carbohydrate chains branched on rhamnogalacturonan belonging to the matrix of pectins (McCann and Roberts, 1991; Carpita and Gibeaut, 1993). Historically, seed cell wall galactans were first detected in 1892 but the characterization of $\beta$-(1,4)-galactan as a distinct polysaccharide in seeds of Lupinus albus was demonstrated by Hirst in 1947 (Hirst et al., 1947). By studying four species of lupins, Al-Kaisey and Wilkie (Al-Kaisey and Wilkie, 1992) demonstrated the presence of two types of galactan polysaccharides in their seeds. So, a $\alpha-(1,3),(1,6)$ linked galactan with some 4-linkages and a $\alpha-(1,4)$ galactan substituted by L-arabinofuranose were characterised. Lupinus polyphyllus and Lupinus angustifolius $\mathrm{L}$. seeds contained a galacto-arabino rhamnogalacturonan (Al-Kaisey and Wilkie, 1992; Cheetham et al., 1993). Consequently, Lupinus polyphyllus seeds were currently used to produce larger amount of galactans. Finally, note to mention that linear $\beta$ - $(1,4)$-galactans were isolated from the lemon peels (Labavitch et al., 1976), from potato tubers (Wood and Siddiqui, 1972), from Norwegian spruce compresssion wood (Bouveng and Meier, 1959) and from Strychnosnux-vomica L. seeds (Andrews et al., 1954).

Brillouet and Riochet (Brillouet and Riochet, 1983) have described the correlation between the galactose amount and rhamnose:galacturonic acid ratio in the cell wall polysaccharides of lupin cotyledons. This correlation was easily attributed to an increase in sites (rhamnosyl residues) for anchoring galactan side chains to the pectic backbone. In fact, galactans associated with arabinans, as arabinogalactan, constituted the neutral pectic substance present at low amounts in plant cell wall. Pectic galactans were characterized as $\beta$-(1,4)-linked linear polymers which could possess a small number of 6-linked residues (Ghosh and Das, 1984). The arabinogalactans are present in two distinct types of macromolecules in plant cell walls.

Table 5 - Galactan plants producers.

\begin{tabular}{|c|c|c|c|c|}
\hline Species & Sugar units & Linkages & Substitutions & References \\
\hline Acacia glomerosa & D-Gal, L-Ara & $\beta-(1,3)$ & Met & $\begin{array}{l}\text { León de pinto et al., } \\
2001\end{array}$ \\
\hline Acacia tortuosa & $\begin{array}{l}\text { Gal, Ara, Xyl, } \\
\text { AcGlu }\end{array}$ & $\beta-(1,3)$ & Met & $\begin{array}{l}\text { León de pinto et al., } \\
1998\end{array}$ \\
\hline Strychnos sp & Ara, Gal, Rha & $\begin{array}{l}\beta \text {-(1,3)-Galp, } \beta \text {-(1,4)-Galp } \\
\alpha-(1,4) \text {-Araf, } \alpha-(1,5) \text {-Araf }\end{array}$ & - & Corsaro et al., 1995 \\
\hline $\begin{array}{l}\text { Acacia } \\
\text { macracantiha }\end{array}$ & $\begin{array}{l}\text { Gal, Ara, Rha, } \\
\text { AcGlu }\end{array}$ & $\beta-(1,3)$ & Met & Martinez et al., 1996 \\
\hline Raphanus sativus & Ara, Gal, Glc, Xyl & $\beta-(1,3), \beta-(1,6)$ & - & $\begin{array}{l}\text { Tsumuraya et al., } \\
1988\end{array}$ \\
\hline Pinus radiata & Gal, Ara & - & - & Fenemor, 1984 \\
\hline $\begin{array}{l}\text { Atractylodes } \\
\text { lancea }\end{array}$ & $\begin{array}{l}\text { Ara, Gal, Xyl, Rha, } \\
\text { Fuc, Man, Glc }\end{array}$ & $\beta-(1,3), \beta-(1,6)$ & - & Yu et al., 2001 \\
\hline Angelica acutiloba & Ara, Rha, Gal, Glc & $\beta-(1,3), \beta-(1,4)$ & - & Zhang et al., 1996 \\
\hline
\end{tabular}

\section{Arabinogalactan I}

Perez in 2000 described type I arabinogalactans (AGs) which are abundant in primary walls of dicotyledonous plant tissues including many fruits (Perez et al., 2000). They comprise a main backbone of (1-4)-linked $\beta$-D-Galp to which short side chains of (1-5)-linked $\alpha$-Araf are attached at the $\mathrm{O} 3$ position. Ferulic acid has been found attached to some arabinose and galactose residues in some tissues such as sugar beet (Ralet et al., 2005). 


\section{Arabinogalactan II}

Type II Arabinogalactans are highly complex polysaccharides which are generally associated with proteins and described as arabinogalactan proteins (AGPs). They are widely distributed in the plant kingdom, and they are one of the most structurally complex macromolecules in nature. These proteoglycans showed typically molecular weights between 60 to $300 \mathrm{kDa}$, a composition including more than $90 \%$ of carbohydrates and a core polypeptide that was usually rich in Hyp, Ala, Ser, and Thr (Serpe and Nothnagel, 1999).

Type II Arabinogalactans habe been extracted along with pectic polymers with they were probably covalently linked on rhamnogalacturonan (Vincken et al., 2003). They exhibit highly complex structures comprising a highly branched galactan core of $(1,3)$ - and $(1,6)$-linked $\beta$-D-Galp residues. Short side chains of $(1,6)$-linked $\beta$-DGalp including between one and three residues in length are present. Galactosyl residues in these side chains are often substituted with terminal $\alpha$-LAraf attached at O3 or O6. Small amounts of GlcpA may also be present. A low molecular weight type II arabinogalactan associated with a hydroxyproline-rich peptide (arabinogalactan proteins, AGPs) was isolated from wheat flour (Fincher and Stone, 1974).

Finally, sulfated galactan have been isolated from marine plants such as the marine sea grass Rupia maritima (Aquino et al., 2005). This family of marine plant is a vascular flowering plant (Angiospermae, Spermatophyta) known to grow in highly saline marine environments. As described by Aquino et al. (2005), the chemical backbone structure of Rupia maritima sulfated D-galactan was only composed of tetrasaccharide repeating units made up of [,3)- $\beta$-D-Galp-2(OSO 3$)-(1,4)-\alpha-$ D-Galp-(1,4)- $\alpha$-D-Galp-(1,3)- $\beta$-D-Galp-4(OSO ${ }_{3}^{-}$) -(1]n. As mentioned by authors, this galactan is a regular structure contrary to red algae galactan sulfate where glycosidic units are distributed in an alternating sequence. It was suggested that the sulfo ester of this galactan could influence the caption of salt ions from sea water in order to physiologically regulate the osmosis in the marine plante (Aquino et al., 2005).

\section{GALACTANS FROM ANIMAL ORIGINS}

As presented previously, sulfated galactans are largely distributed in nature in a great variety of organisms. In the animal kingdom, sulfated polysaccharides such as glycosaminoglycans have been identified in large amounts in vertebrate tissues (Assaro and Dietrich, 1977; Mathews, 1975) and invertebrate species as Chordata tunicata, Ciona intestinalis and Herdmania monus which constituted a rich source of sulfated polysaccharides with original structures (Mourao and Perlin, 1987; Pavao et al., 1998). Therefore, lot of studies have described that the marine invertebrates ascidians families contained a very high quantity of sulfated galactans (Mourao and Perlin, 1987; Pavao et al., 1989; Santos et al., 1992; Pavao et al., 1998). Note that these sulfated galactans from invertebrates showed the same structural pattern of simple and well-defined units found in invertebrate sulfated fucans from seacucumber and from the egg jelly coat of seaurchins (Pomin, 2009). Then, the regulated backbone structures of theses sulfated galactans was characterized as [,3)- $\alpha$-L-Galp-2( $\left.\mathrm{SO}_{3}\right)-(1,] \mathrm{n}$ from Echinometra lucunter (Alves et al., 1997); [4)- $\alpha$-L-Galp-2[1)- $\alpha$-L-Galp-3( $\left.\left(\mathrm{OSO}_{3}\right)\right]-3\left(\mathrm{OSO}_{3}\right)$ $(1]$,$n from Styela plicata (Mourao et al., 1987);$ [,4)- $\alpha$-L-Galp-3( $\left.\mathrm{SO}_{3}\right)-(1,] \mathrm{n}$ from Herdmania monus (Santos et al., 1992) and sulfated [3)- $\beta$-DGalp-(1,4)- $\alpha$-Gal-(1,]n from both Botryocladia occidentalis and Gelidium crinale (Fonseca et al., 2008).

\section{GALACTANS FROM MICROBIAL ORIGINS}

In the light of the precedent paragraphs and as many of us know, the polysaccharides find origin in all the nature. The polysaccharides market has been booming in terms of biotechnological operations and value-addition. To meet the constantly increasing demand and to produce the newer types/properties, the production of biopolymers by the bacterial fermentation appears as an important alternative to the animal, plant and seaweed exploitation. Some important advantages 
of the bacterial polysaccharides are: (i) easy way of production without any contraint of seasons, extraction and purification without use of the drastic conditions, etc. (Delattre et al., 2009). These polysaccharides from microorganisms have been described for their biological activities (Sekina et al., 1985). Consequently, to adapt to today's needs in biotechnology field, screening of new and original microorganism from a wide part of living organism environments has become the new challenge of modern microbiotechnologists. Some bacteria are known as producer of galactans. For example Methylobacterium sp. producing a $100 \%$ galactan (D-galactopyranose) was isolated by Verhoef et al. (2003). Other galactan could be produced by Lactococcus lactis subspecies cremoris H414 (Gruter et al., 1992) or Lactococcus lactis subsp. cremoris B891 (Van Casteren et al., 2000). Finally, it is interesting to mention that as galactan from seaweed, the bacterial galactan from Bifidobacteria catenulatum presented biological activities and notably effect in healing gastric ulcers (Nagaoka et al., 1994).

\section{GALACTANS FROM FUNGAL ORIGINS}

Literature speaking about galactan from fungi is little but exists. The genus Pleurotus is known as a producer of this polysaccharide. Looking at structures, the main chains consisted of $6-\alpha-D-$ galactopyranoses in the case of Pleurotus eryngii (Carbonero, 2008) and Inonotus levis (Vinogradov and Wasser, 2005), but 4- $\alpha$-D-galactopyranoses were detected for P. ostreatoroseus (Rosado et al., 2003). In all cases, parts of galactose were methylated in position 3 .

\section{MAIN APPLICATIONS POLYSACCHARIDES BIOTECHNOLOGY}

\section{Red algae polysaccharide in biotechnology: example of sulfated galactans as bioactive compounds}

The seaweed, including red algae is used since a long time in the world for food, medical, and more recently, biotechnology. An assessment was conducted in 1999 (Zemke-White and Ohno, 1999) concerning the production and use of seaweed around the world for the years 19941995. They determined that about the 221 species of seaweed used, 145 were for food and 101 for the production of phycocolloids. 32 were Chlorophyceae (green algae), 124 were Rhodophyceae (red algae) and 65 were Pheophyceae (brown algae). The origin of the algae is twofold: either they are derived from natural production worldwide ( 2 million tons of dry weight), or they come from culture, which tonnage represents 1 million tons of dry weight. It is interesting to note that since 1984 the global production of algae grew by $119 \%$, thus underscoring the continued growth in the use of algae. Apart the industrial uses, some of these algae were directly used for human consumption for their great nutritional interest (Zemke-White and Ohno, 1999). Regarding industrial applications of galactans extracts from algae, they are generally around the texture (gelling and thickening properties), but now they are also used as cosmetic and biomedical products.

Unconnected to their natural biological implication in animal, algae and plants, galactans could act as potential pharmacological product in mammalian systems. For example, sulfated galactan could modulate: antiviral (Harrop et al., 1992; Pujol, 1996; Carlucci et al., 1997; Caceres et al., 2000), antimetastatic (Coombe et al., 1987) antiangiogenic (Cumashi et al., 2007), antiinflammatory (Berteau and Mulloy, 2003); antiadhesive (Berteau and Mulloy, 2003), anticoagulant (Pereira et al., 2002) or antithrombotic (Mourao and Pereira, 1999; Berteau and Mulloy, 2003) activities.

Nevertheless, in some cases, the polysaccharide application on animal tissues induced only a weak biological activity, without doubt due to the polymer high molecular weight (Delattre et al., 2005). In fact, the large size of polysaccharides locally applied on animal tissues could be a problem for their diffusion inside them (Delattre et al., 2005). So, low molecular weight polysaccharides sequences such as oligosaccharide structures could interact more efficiently with specific membrane receptors as described for example in the case of heparan sulfate (Yu et al., 2000). Consequently, oligosaccharides from depolymerization of galactans were used because of their high biological activity on cells (Delattre et al., 2005). 


\section{Oligogalactans from polysaccharides and their applications in biotechnology}

It is now well established that carbohydrateprotein interactions play a major rule in numerous biological processes (Delattre et al., 2005; Varki, 1993). Then, it appeared practical to exploit the potential of bioactive polysaccharides and their derivatives such as oligosaccharides and low molecular weigh (LMWs) polysaccharides. Generally, oligosaccharides are mostly considered for their potentialities as cellular signalling agents. Therefore, some oligosaccharides acting like signalling molecules (the term hormone is sometime employed) on various organisms arouse actually a great interest. Then, their role in cellular development is very important notably in cellular and subcellular communication, signalisation and interaction (Delattre et al., 2005; Varki, 1993). Lot of oligosaccharides have been described as being implicated in a wide variety of biological activities such as anticoagulant, cofactor for growth factor, cytokines and chemokines production, tumorigenesis, signalling molecules in responses to infection or other cellular damages, regulator of blood coagulation, against viral and bacterial infections (Delattre et al., 2005). Then, according to the important relationship between oligosaccharides structures and biological functions, a lot of industrial applications can be investigated. This context has led to worldwide research in the area of oligosaccharides production. However, even if prospective applications of polysaccharides were demonstrated, very few studies and biological applications have been developed using oligosaccharides produced by depolymerisation of polysaccharides and more especially sulfated galactans.

Lot of evidences have indicated that the molecular weight $(\mathrm{Mw})$, structural features and content in sulfur groups of seaweed galactans were important factors which influence their biological behaviors (Franz and Alban, 1995; Sugawara and Ishizaka 1982). Therefore sulfated galactans such as carrageenans and their depolymerized products, have been shown to possess biological activities such as immunomodulation and antitumor activity (Yuan et al., 2006). Sulfated galactan oligosaccharides were described for their antitumor activities on Ehrlich ascites cells, Meth-A tumor, and mammary adenocarcinoma (Coombe et al., 1987; Noda et al., 1989).
Among mammalian, glycosaminoglycans (GAGs) and more essentially oligo-glycosaminoglycans from heparin, heparan sufate, hyaluronate and chondroitin sulphate have been identified as implicated in a wide variety of biological processes as, regulator of blood coagulation, cofactor for growth factor, tumorigenesis, cytokines and chemokines production, assisting viral and bacterial infections, and signalling molecules in responses to infection or other cellular damages (Pineo and Hull, 1997). Consequently, biological activities of oligosaccharides from plant and algae suggest that these compounds may have a variety of actions on animal cells. In fact, in regard to their homologies with GAG structure, sulfated polysaccharides (galactan, ulvan and fucoidan) extracted from marine algae were considered as sources of marine molecules with potential applications in medicine (Farias et al., 2000).

\section{MAIN STRATEGIES DEVELOPED FOR THE PRODUCTION OF OLIGOSACCHARIDES}

Even if the potentialities of oligosaccharides are unquestionable, in most cases, the lack of oligosaccharides scale up production strategies is the main drawback limiting their applications. Consequently, the improvement of oligosaccharides engineering strategies arouses currently a great interest. Different industrial ways can be investigated for the scale up production of oligosaccharidic structures. Generally, bioactive oligosaccharides come from either (i) synthesis (using enzymatic or chemical engineering): or (ii) polysaccharide depolymerization (using physical, chemical or enzymatic methods). The best way to degrade the polysaccharides in homogenous oligosaccharides structures corresponds to the bioconversion of polysaccharide by enzymic degradation. So, polysaccharide cleavage enzymes are widely exploited to degrade various polysaccharides, as polysaccharide hydrolases used to degrade neutral polysaccharides, and polysaccharide hydrolases and lyases used to degrade anionic polysaccharides.

Various physical methods are commonly used to depolymerize a large amount of polysaccharides. From them, microwave irradiation was developed, firstly in the extraction of plant polysaccharides and secondly in oligomers production strategies. 
The main advantages of microwaves irradiations are to produce an efficient thermal energy source for shorter reaction times and so, to cleave the polysaccharides. Nevertheless, a low proportion of oligosaccharidic families are generally produced. In this way microwaves treatment applied to algae galactans conducted to the production of various low molecular weight polysaccharides with antitumor activities (Zhou et al., 2004).

Many polysaccharides could be chemically depolymerised by acidic treatment to produce a large amount of oligosaccharides. The depolymerization of polysaccharides is generally realized by heating in diluted or concentrated acid (2M) such as $\mathrm{HCl}, \mathrm{H}_{2} \mathrm{SO}_{4}$, TFA, formic or nitrous acid. That's the way, a lot of oligogalactans such as oligo-carrageenans (Hjerde et al., 1994), oligoarabinogalactans from the wood of western larch (Ponder, 1998), and smalls galactans chains from Lupin seeds (Vogl et al., 2000) were produced and isolated.

Even if all these physico-chemical methods are very efficient to cleave glycosidic linkages, there are some drawbacks. In fact, polymers cannot be totally converted into oligomers (but rather LMW) and these last are in majority randomly produced. Consequently, for all these disadvantages, enzymatic depolymerization is generally a good alternative to resolve the specific oligosaccharides productions. Then, many genera of marine bacteria have been employed to produce galactanases, such as Alteromonas agarlyticus (Potin et al., 1993) or Vibrio (Araki et al., 1998).

\section{CONCLUSION}

To conclude, often described as very simple macromolecules extracted from seaweeds and used in industry for their rheological properties, galactans have been identified as very complex polysaccharides. Their natural functions are not always clear and are probably not only limited to structural function in plant cell wall. Effectively, more and more papers have detailed galactans and more especially sulfated galactans as biological active compounds in various cell types or about full organisms. Even if the sufate content appeard as an essential structural feature associated with biological activity, it is probably not the sole as not sulfated galactans from terrestrial plants showed interesting potentialities. The nature of glycosidic bonds between two galactose residues, their isomeric specificities, their degrees of substitution by other monosaccharides and no sugars compounds such as pyruvate or methyl seem to play a major role in their biological function. Recent progresses in structural characterization of these polysaccharides will conduct in a next future to a better understanding of their structural evolution during the different steps of life of an organism. This will lead to a tentative of correlation between structure and function but also to a more interesting exploitation of terrestrial plant and seaweeds for industrial application. This point as the development of processes for specific extraction and purification of galactans with well defined features will be essential for future developments of these compounds in markets with higher values to those actually exploited.

\section{REFERENCES}

Akari, C. (1996), Some recent studies on the polysaccharides of agarophytes. Proceedings of the international seaweed symposium, 5, 3-17

Al-Kaisey, M.T., Wilkie, C.B. (1992), The polysaccharides of agricultural lupin seeds. Carbohyd. Res., 227, 147-161

Alves, A.P., Mulloy, B., Diniz, J.A., Mourao, P.A. (1997), Sulfated Polysaccharides from the Egg Jelly Layer Are Species-specific Inducers of Acrosomal Reaction in Sperms of Sea Urchins. J. Biol. Chem., 272, 6965-6971

Anderson, N.S., Dolan, T.C., Rees, D.A. (1973), Carrageenans. VII. Polysaccharides from Eucheuma spinosum and Eucheuma cottonii. The covalent structure of iotacarrageenan. Journal of the Chemical Society Perkin Transactions 1, 19, 2173-2176

Andrews, P., Hough, L., Jones, J.K.N. (1954), The galactan of Strychnosnux-vomica seeds. J. Chem. Soc., 806-810

Aquino, R.S., Landeira-Fernandez, A.M., Valente, A.P., Andrade, L.R., Mourao, P.A.S. (2005), Occurrence of sulfated galactans in marine angiosperms: Evolutionary implications. Glycobiology, 15, 11-20

Araki, T., Hayakawa, M., Lu, Z., Karita, S., Morishita, T. (1998), Purification and characterization of agarases from a marine bacterium, Vibrio sp. PO-303. J Mar Biotechnol., 6, 260-265

Assaro, C.M.F., Dietrich, C.P. (1977), Distribution of sulfated mucopolysaccharides in invertebrates. $J$. Biol. Chem., 252, 2254-2261

Bellion, C., Brigand, G., Prome, J.C., Welti, D., Bociek, S. (1983), Identification et caractérisation des précurseurs biologiques des carraghénanes par 
spectroscopie de R.M.N.- ${ }^{13}$ C. Carbohyd. Res., 119, $31-48$

Berteau, M., Mulloy, B. (2003), Sulfated fucans, fresh perspectives: structures, functions, and biological properties of sulfated fucans and an overview of enzymes active toward this class of polysaccharide. Glycobiology, 13(6), 29-40

Bilan, M.I., Vinogradova, E.V., Shashkov, A.S., Usov, A.I. (2007), Structure of a highly pyruvylated galactan sulphate from the pacific green alga Codium yezoense (Bryopsidales, Chlorophyta). Carbohyd. Res. 342, 586-596

Bouveng, H.O., Meier, H. (1959), Galactan from Norwegian spruce compression wood. Acta Chem. Scand., 22, 1884-1889

Brasch, D.J., Chang, H.M., Chuah, C.T., Melton, L.D. (1981), The galactan sulfate from the edible, red alga Porphyra columbina. Carbohyd. Res. 97, 113-125

Brillouet, J.M., Riochet, D. (1983), Cell wall polysaccharides and lignin in cotyledons and hulls of seeds from various lupins (Lupinus L.) species. J. Sci. Food Agric., 34, 861-868

Carbonero, E.R., Gracher, A.H., Rosa, M.C., Torri, G., Sassaki, G.L., Gorin, P.A., Iacomini, M. (2008), Unusual partially 3-O-methylated alpha-galactan from mushrooms of the genus Pleurotus. Phytochem., 69(1), 252-257

Caceres, P., Carlucci, M.J., Damonte, E.B., Matsuhiro, B., Zuniga, EA. (2000), Carrageenans from chilean samples of Stenogramme interrupta (Phyllophoraceae): structural analysis and biological activity. Phytochem., 53, 81-86

Calumpong, H.P., Maypa, A., Magbanua, M., Suarez, P. (1999), Biomass and agar assessment of three spesies of gracilaria from Negros Island, Central Philippines. Hydrobiologia, 398/399, 173-182

Carlucci, M.J., Scolaro, L.A., Errea, M.I., Matulewicz, M.C., Damonte, E.B. (1997), Antiviral activity of natural sulphated galactans on herpes virus multiplication in cell culture. Planta Med., 63, 429432

Carpita, N.C., Gibeaut, D.M. (1993), Structural models of primary cell walls in flowering plants: consistency of molecular structure with the physical properties of cell wall during growth. Plant J., 3, 1-30

Chattopadhyay, K., Mateu, C.G., Mandal, P., Pujol, C.A., Damonte, E.B., Ray, B. (2007), Galactan sulfate of Grateloupia indica: Isolation, structural features and antiviral activity. Phytochem. 6, 14281435

Chen, L., McLachlan, J. (1972), The life history of Chondrus crispus. Can. J. Bot., 50, 1055-1066

Cheetham, N.W., Cheung, P.C.K., Evans, A.J. (1993), Structure of the principal non-starch polysaccharide from the cotyledons of Lupinus angustifolius (Cultivar Gungurru). Carbohyd. Pol., 22, 37-47
Chiovitti, A., Bacic, A., Craik., D.J., Kraft, G.T., Liao, M.L. (2004), A nearly idealized 6'-O-methylated $\eta$ carrageenan from the Australian red alga Claviclonium ovatum (Acrotylaceae, Gigartinales). Carbohydr. Res., 339, 1459-1466

Chiovitti, A., Bacic, A., Craik, D.J., Kraft, G.T., Liao, M.L., Falshaw, R., Furneaux, R.H. (1998), A pyruvated carrageenan from Australian specimens of the red alga Sarconema filiforme. Carbohyd. Res., 310, 77-83

Ciancia, M., Matulewicz, M.C., Cerezo, A.S. (1993), Lgalactose - containing carrageenan from the carrageenophyte Gigartina skottsbergii. Phytochem., 34, 1541-1543

Coombe, D.R., Parish, C.R., Ramshaw, I.A., Snowden, J.M. (1987), Analysis of the inhibition of tumour metastasis by sulphated polysaccharides. Int. J. Cancer, 39(1), 82-88

Corsaro, M.M., Giudicianni, I., Lanzetta, R., Marciano, C.E., Monaco, P., Parrilli, M. (1995), Polysaccharides from seeds of Strychnos species. Phytochem., 39, 1377-1380.

Craigie, J. (1990), Cell walls. In: Cole K, Sheath R (eds) Biology of the red algae. Cambridge Univ. Press, Cambridge, pp. 221-257

Cumashi, A., Ushakova, N. A., Preobrazhenskaya, M. E., D'Incecco, A., Piccoli, A., Totani, L., Tinari, N., Morozevich, G. E., Berman, A. E., Bilan, M. I., Usov, A. I., Ustyuzhanina, N. E., Grachev, A. A., Sanderson, C. J., Kelly, M., Rabinovich, G.A., Iacobelli, S., Nifantiev, N. E., (2007), Consorzio Interuniversitario Nazionale per la Bio-Oncologia Italy. Glycobiology, 17, 541-552

Delattre, C., Michaud, P., Courtois, B., Courtois, J. (2005), Oligosaccharides engineering from plants and algae applications in biotechnology and therapeutics. Minerva Biotec., 17, 107-117

Delattre, C., Laroche, C., Michaud, P. (2009), Bacterial and fungal polysaccharides produced by fermentation - An overview. Advances in fermentation Technology Asiatech Publishers, Inc., New Delhi., pp 484-521

DiNinno, V., McCandless, E., Bell, R., (1979), Pyruvic acid derivative of carrageenan from a marine red algae (Petrocelis species). Carbohyd. Res., 71, C1-C4

Duarte, M.E.R., Noseda, M.D., Cardoso, M.A., Tulio, S., Cerezo, A.S. (2002), The structure of a galactan sulfate from the red seaweed Bostrychia montagnei. Carbohyd. Res., 337, 1137-1144

Estevez, J.M., Ciancia, M., Cerezo, A.S. (2000), The system of low-molecular-weight carrageenans and agaroids from the room-temperature-extracted fraction of Kappaphycus alvarezii. Carbohyd Res., 2000, 325, 287-299 
Estevez, J.M., Ciancia, M., Cerezo, A.S. (2004), The system of galactans of the red seaweed, Kappaphycus alvarezii, with emphasis on its minor constituents. Carbohyd. Res. 339, 2575-2592Estevez, J.M., Ciancia, M., Cerezo, A.S. (2008), The system of sulfated galactans from the red seaweed Gymnogongrus torulosus (Phyllophoraceae, Rhodophyta): Location and structural analysis. Carbohyd. Polym., 73, 594-613

Falshaw, R., Furneaux, R.H., Stevenson, D.E. (2005), Structural analysis of carrageenans from the red alga, Callophyllis hombroniana Mont. Kütz (Kallymeniaceae, Rhodophyta). Carbohyd. Res., 340, 1149-1158

Falshaw, R., Bixler, H.J., Johndro, K., (2003), Structure and performance of commercial-2 carrageenan extracts. Part III. Structure analysis and performance in two dairy applications of extracts from the New Zealand red seaweed, Gigartina atropurpurea. Food Hydrocolloids, 17, 129-139

Falshaw, R., Bixler, H.J., Johndro, K. (2001), Structure and performance of commercial kappa-2 carrageenan extracts: I- Structure analysis. Food Hydrocolloid, 15, 441-452

Falshaw, R., Furneaux, R.H. (1995), Carrageenans from the tetrasporic stages of Gigartina clavifera and Gigartina alveata (Gigartinaceae, Rhodophyta). Carbohyd. Res., 276, 155-165

Falshaw, R., Furneaux, R.H. (1998), Structural analysis of carrageenans from the tetrasporic stages of the red algae, Gigartina lanceata and Gigartina chapmanii (Gigartinaceae, Rhodophyta). Carbohyd. Res., 307, 325-331

Farrant, A.J., Nuun., J.R., Parolis, H. (1971), Sulphated polysaccahrides of the Grateloupiaceae family; Part VI. A polysaccahrides from Pachymenia Carnosa. Carbohyd. Res. 19, 161-168

Farias, W.R.L., Valente, A.P., Pereira, M.S., Mourao, P.A.S. (2000), Structure and anticoagulant activity of sulphated galactans: isolation of a unique sulphated galactan from the red algae Botryocladia occidentalis and comparison of its anticoagulant action with that of sulphated galactans from invertebrates. J. Biol. Chem., 275, 299-307

Farrant, A.J., Nuun, J.R., Parolis, H. (1972), Sulphated polysaccahrides of the Grateloupiaceae family; Part VII. Investigation of the acetolysis products of a partially desulphated sample of polysaccharide of Pachymenia Carnosa. Carbohyd. Res., 25, 283-292

Fenemore, D.R. (1984), Characterization of a 3-linked galactan from pinus radiata callus cells. Phytochem., 23, 591-593

Fincher, G.B., Stone, B.A. (1974), A water-soluble arabinogalactans-peptide from wheat endosperm. Australian Journal of Biological Sciences, 27, 117132
Fonseca, R.J.C., Oliveira, S.N.M.C.G., Melo, F.R., Pereira, M.G., Benevides, N.M.B., Mourao, P.A.S. (2008), Slight differences in sulfation of algal galactans account for differences in their anticoagulant and venous antithrombotic activities. Thromb. Haemost, 99, 539-545.

Franz, G., Alban, S. (1995), Structure-activity relationship of antithrombotic polysaccharide derivatives. Int. J. Biol. Macromol., 17(6), 311-314

Freile-Pelegriny, Y. (2000), Does storange time influence yield and agar properties in the tropical agarophyte Gracilaria cornea. J. Appl. Phycol. 12, 153-158

Friedlander, M, Dawes, C.J. (1984), Studies on spore release and sporeling growth from carpospores of Gracilaria foliifera (Forsskål) Børgesen var. angustissima (Harvey) Taylor. II. Photosynthetic and respiratory responses. Aquatic Botany, 19, 233-241

Furneaux, R.H., Stevenson, T.T. (1990), The xylogalactan sulfate from Chondria macrocarpa (Ceramiales, Rhodophyta). Hydrobiologia, 204/205, 615-620

Garon-lardiere, S. (2004), Etude structurale des polysaccharides pariétaux de l'algue rouge Asparagopsis armata (Bonnemaisoniales). Thesis. Chemistry. Université de Bretagne Occidentale

Ghosh, R., Das, A. (1984), Structure of the $\beta$-Dgalactan isolated from the pods of Dolichos lablab Linn. Carbohyd. Res., 126(2), 287-296

Greer, C.W., Yaphe, W. (1984), Characterization of hybrid (beta-kappa-gamma) carrageenan from Eucheuma gelatinae J. Agardh (Rhodophyta, Solieriaceae) using Carrageenases, infrared and ${ }^{13} \mathrm{C}$ Nuclear Magnetic Resonance Spectroscopy. Bot. Mar., 27, 473-478

Gruter, M., Leeflang, B.R., Kuiper, J., Kamerling, J.P., Vliegenthart, J.F.G. (1992), Structure of the exopolysaccharide produced by Lactococcus lactis subspecies cremoris H414 grown in a defined medium or skimmed milk. Carbohyd. Res., 231, 273291

Harrop, H.A., Rider, C.C., Coombe, D.R. (1992), Sulphated polysaccharides exert anti-HIV activity at differing sites. Biochem. Soc. Trans., 20, 163S

Hirase, S., Araki, C., Watanabe, K. (1967), Component sugars of the polysaccharide of the red seaweed Grateloupia elliptica. Bull. Chem. Soc. Jap., 40, 1445-1448

Hirase, S., Watanabe, K. (1972), Fractionation and structural investigation of furonan. In Proceedings of the VII ${ }^{\text {th }}$ International Seaweed Symposium Edited by K. Nisizawa. Sapporo: University of Tokyo Press, pp. 451-454

Hirst, E.L., Jons, J.K.N., Walder, W.O. (1947), Pectic substances. Part 7: the constitution of the galactan from Lupinus albus. J. Chem. Soc., 1225-1229 
Hjerde, T., Kristiansen, T.S., Stokke, B.T., Smidsroed, O., Christensen, B.E. (1994), Conformationdependent depolymerization kinetics of polysaccharides studied by viscosity measurements. Carbohyd. Poyml., 24, 265-275

Kloareg B., Quatrano, R.S. (1988), Structure of the cell walls of marine algae and ecophysiological functions of the matrix polysaccaharides. Oceanogr. Mar. Biol. Annu. Rev., 26, 259-315

Knutsen, S., Myslabodski, D., Larsen, B., Usov, A. (1994), A modified system of nomenclature for red algal galactans. Bot. Mar. 37, 163-169

Labavitch, J.H., Freeman, L.E., Albersheim, P. (1976). Purification and characterisation of $\beta$-1,4-galactanase which degrades a structural component of the primary cell wall of dicots. J. Biol. Chem., 251, 5904-5910

Lahaye, M. (2001), Development on gelling algal galactans, their structure and physic chemistry. $J$. Appl. Phycol. 13, 173-184

Leon de Pinto, G., Martinez, M., Sanabria, L. (2001), Structural features of the polysaccharide gum from Acacia glomerosa. Food Hydrocolloids, 15, 461-467

Leon de Pinto, G., Martinez, M., De Bolano, L.M., Rivas, C., Ocando, E. (1998), The polysaccharide gum from Acacia tortuosa. Phytochem., 47, 53-56.

Liao, M.L, Chiovitti, A., Munro, S.L.A., Craik, D.J., Kraft, G.T., Bacic, A. (1996), Sulfated galactans from Australian specimens of the red alga Phacelocarpus peperocarpos (Gigartinales, Rhodophyta). Carbohyd. Res., 296, 237-247

Martínez, M., León de Pinto, G., Rivas, C., Ocando, E. (1996), Chemical and spectroscopic studies of the gum polysaccharide from Acacia macracantha. Carbohyd. Polym., 29, 247-252

Mathews, M.B. (1975), Connective tissue, macromolecular structure and evolution, SpringerVerlag, Berlin, pp. 93-206

Matulewicz, M.C., Ciancia, M., Noseda, M.D., Cerezo, A.S. (1989), Carrageenan systems from tetrasporic and cystocarpic stages of Gigartina skottsbergii. Phytochem., 28, 2937-2941

Matulewicz, M.C., Ciancia, M., Noseda, M.D., Cerezo, A.S. (1990), Methylation analysis of carrageenans from tetrasporic and cystocarpic stages of Gigartina skottsbergii. Phytochem., 29, 3407-3410

Matsuhiro, B., Urzua, C.C. (1992), Heterogeneity of carrageenans from Chondrus crispus. Phytochem., 31, 531-534

Matsuhiro, B., Conte, A. F., Damonte, E. B., Kolender, A. A., Matulewicz, M. C., Mejías, E. G., et al. (2005), Structural analysis and antiviral activity of a sulfated galactan from the red seaweed Schizymenia binderi (Gigartinales, Rhodophyta). Carbohyd. Res., 340, 2392-2402.

McCann, M.C., Roberts, K. (1991), Architecture of the primary cell wall, in: Lloyd C.W. (Ed.), The Cytoskeletal Basis of Plant Growth and Form, Academic Press, London, pp. 109-129
McCandless E.L., Craigie, J.S. (1974), Reevaluation of seasonal factors involved in carrageenan production by Chondrus crispus: carrageenans of carposporic plants. Bot. Mar., 17, 125-129

McCandless E.L., Craigie, J.S., Walter, J.A. (1973), Carrageenans in thegarnetophytic and sporophytic stages of Chondrus crispus. PIanta, 112, 201-212

McCandless, E.L., West, J.A., Guiry, M.D. (1983), Carrageenan patterns in the Gigartinaceae. Biochem. Syst. Ecol., 11, 175-182

McCandless, E.L., West, J.A., Guiry, M.D. (1982), Carrageenan patterns in the Phyllophoraceae. Biochem. Syst. Ecol., 10, 275-282

Miller, I., (2003), The chemical structure of galactans from some New Zealand red algae. Bot., Mar. 46, $572-577$

Miller, I.J., Falshaw, R., Furneaux, R.H. (1995), Structural analysis of the polysaccharide from Pachymenia lusoria (Cryptonemiaceae, Rhodophyta). Carbohyd. Res., 268, 219-232

Morrice, L.M., McLean, M.W., Long, W.F., Williamson, F.B. (1983), Porphyran primary structure. An investigation using beta-agarase I from Pseudomonas atlantica and ${ }^{13} \mathrm{C}-\mathrm{NMR}$ spectroscopy. Eur. J. Biochem., 133(3), 673-684

Morris, E.R., Rees, D.A. (1980), Cation-specific aggregation of carrageenan helices: domain model of polymer gel structure. J. Mol. Biol., 138, 349-362

Mourao, P.A., Pereira, M.S. (1999), Searching for alternatives to heparin: sulfated fucans from marine invertebrates. Trends Cardiovasc. Med., 9, 225-232

Mourao, P.A.S., Perlin, A.S. (1987), Structural features of sulfated glycans from the tunic of Styela plicata (Chordata-Tunicata): a unique occurrence of Lgalactose in sulfated polysaccharides. Eur. J. Biochem., 166, 431-436

Nagaoka, M., Hashimoto, S., Watanabe, T., Yokoko, Mori, Y. (1994), Anti-ulcer effects of lactic acid bacteria and their cell wall polysaccharides. Biol. Pharm. Bull. 17, 1012-1017

Noda, H., Amano, H., Arashima, K., Nizizawa, K. (1989), Antitumor activity of marine algae. Hydrobiologia, 204-205

Pavao, M.S.G., Albano, R.M., Lawson, A.M., Mourao, P.A.S. (1989), Structural heterogeneity among unique sulfated L-galactans from different species of ascidians (tunicates). J. Biol. Chem., 264, 9972-9979

Pavao, M.S.G., Aiello, K.R.M., Werneck, C.C., Silva, L.C.F., Valente, A.P., Mulloy, B., Colwell, N.S., Tollefsen, D.M., Mourao, P.A.S. (1998), Highly sulfated dermatan sulfates from ascidians: structure versus anticoagulant activity of these glycosaminoglycans. J. Biol. Chem., 273, 2784827857

Pereira, M.S., Melo, F.R., Mourao, P.A. (2002), Is there a correlation between structure and anticoagulant action of sulfated galactans and sulfated fucans? Glycobiology, 12, 573-580 
Penman, A., Rees, D.A. (1973), Carrageenans. IX. Methylation analysis of galactan sulphates from Furcellaria fastigiata, Gigartina canaliculata, Gigartina chamissoi, Gigartina atropurpurea, Ahnfeltia durvillaei, Gymnogongrus furcellatus, Eucheuma isiforme, Eucheuma uncinatum, Aghardhiella tenera, Pachymenia hymantophora, and Gloiopeltis cervicornis. Structure of xi-carrageenan. J. Chem. Soc., 19, 2182-2187

Perez, S., Mazeau, K., Herve du Penhoat, C. (2000), The three-dimensional structures of the pectic polysaccharides. Plant Physiol. Biochem., 38, 37-55

Pickmerse, E., Parsons, M.J., Bailey, R.W. (1973), Composition of Gigartina carrageenan in relation to sporophyte and garnetophyte stages of the life cycle. Phytochern., 12, 2441-2444

Pineo, G.F., Hull, R.D. (1997), Low-molecular-weight heparin: prophylaxis and treatment of venous thromboembolism. Annu Rev. Med., 48, 79-91

Pomin, V.P. (2009), An Overview About the StructureFunction Relationship of Marine Sulfated Homopolysaccharides with Regular Chemical Structures. Biopolymers, 91(8), 601-609

Ponder, G.R. (1998), Arabinogalactan from Western larch. Part IV. Polymeric products of partial acid hydrolysis. Carbohyd. Polym., 36, 1-14

Potin, P., Richard, C., Rochas, C., Kloareg, B (1993), Purification and characterisation of the $\alpha$-agarase from Alteromonas agarlyticus (Cataldi) comb. nov., strain GJ1B. Eur. J. Biochem., 214, 599-607

Pujol, C.A., Errea, M.I., Matulewicz, M.C., Damonte, E.B. (1996), Antiherpetic activity of S1, an algal derived sulphated galactan. Phytother. Res., 10, 410413

Ralet, M.C., André-Leroux, G., Quéméner, B., Thibault, J.F. (2005), Sugar beet (Beta vulgaris) pectins are covalently cross-linked through diferulic bridges in the cell wall. Phytochem., 66(24), 28002814

Rees, D., (1969), Structure, conformation, and mechanism in the formation of polysaccharide gels and networks. Adv. Carbohydr. Chem. Biochem., 24, 267-332

Rees, D.A., Morris, E.R., Thom, D., Madden, J. (1982), In: Aspinall GO (ed) The polysaccharides. Academic, New York, USA . 1982; pp 195-290

Reid, J.S.G. (1985), Structure and function in legumeseed polysaccharides, in: Brett C., Hillman J.R. (Eds.), Biochemistry of the Plant CellWalls, Cambridge Univ. Press, pp. 259-268

Rinaudo, M., (2007). Seaweed polysaccharides. In: Kalmerling JP (ed) Comprehensive glycoscience from chemistry to systems biology, 2, 691-735

Rinaudo, M. (2004), Role of substituents on the properties of some polysaccharides. Biomacromolecules, 5, 1155-1165
Rodriguez, M.C., Merino E.R., Pujol C. A., Damonte, E.B., Cerezo, A.S., Matulewicz, M.C. (2005), Galactans from cystocarpic plants of the red seaweed Callophyllis variegata (Kallymeniaceae, Gigartinales). Carbohyd. Res., 340, 2742-2751.

Rosado, F.R., Carbonero, E.R., Claudino, R.F., Tischer, C.A., Kemmelmeier, C., Iacomini, M. (2003), The presence of partially 3-O-methylated mannogalactan from the fruit bodies of edible basidiomycetes Pleurotus ostreatus 'florida' Berk. and Pleurotus ostreatoroseus Sing. FEMS Microbiol. Lett., 221, 119-124.

Schulze, E., Steiger, E. (1982), Zur Kenntnis des Paragalaktans. Landwirtsch. Vers. Stn., 41, 220-223

Santos, J.A., Mulloy, B., Mourao, P.A.S. (1992), Structural diversity among sulfated L-galactans from ascidians (tunicates): studies on the species Ciona intestinalis and Herdmania monus. Eur. J. Biochem., 204, 669-677

Sekina, K., Toida, T., Saito, M., Kuboyama, M., Kawashima, T., Hashimoto, Y. (1985), A new morphologically characterized cell wall preparation (whole peptidoglycan) from Bifidobacterium infantis with a higher efficacy on the regression of an established tumor in mice, Cancer Res., 45, 13001307

Serpe, M.D., Nothnagel, E.A. (1999), Arabinogalactanproteins in the multiple domains of the plant cell surface. Adv. Bot. Res., 30, 207-289

Smith, D.B., Cook, W.H. (1953), Fractionation of carragening. Arch. Biochem. Biophys., 45, 232-233

Sugawara, I., Ishizaka, S. (1982), Role of various carrageenans in autologous and allogenic mixed lymphocyte reaction. Cell Immunol. , 68(2), 402-409

Takano, R., Iwane-Sakata. H., Hayashi, K., Hara, S., Hirase, S. (1998), Concurrence of agaroid and carrageenan chains in funoran from the red seaweed Gloiopeltis furcata (Cryptonemiales, Rhodophyta). Carbohyd. Polym., 35, 81-87

Tsumuraya, Y., Ogura, K., Hashimoto Y., Mukoyama, H., Yamamoto,. Arabinogalactan-Proteins from Primary and Mature Roots of Radish (Raphanus sativus L.). Plant Physiol., 86, 155-160

Truus, k, Tuvikene, R., Vaher, M., Kailas, T., Toomik, P., Pehk, T. (2006), Structural and compositional characteristics of gelling galactan from the red alga Ahnfeltia tobuchiensis (Ahnfeltiales, the Sea of Japan). Carbohyd. Polym., 63, 130-135

Turnbull, J.E., Field, R.A. (2007), Emerging glycomics technologies. Nature Chem. Biol., 3, 74-77

Van Casteren, W.H.M., De Waard, P., Dijkema, C., Schols, H.A., Voragen, A.G.J. (2000), Structural characterisation and enzymatic modification of the exopolysaccharide produced by Lactococcus lactis subsp. cremoris B891. Carbohyd. Res., 327, 411-422 
Varki, A. (1993), Biological roles of oligosaccharides: all the theories are correct. Glycobiology, 2, 97-130

Verhoef, R., De Waard, P., Schols, H.A., Siikaaho, M., Voragen, A.G.J. (2003), Methylobacterium sp. isolated from a Finnish paper machine produces highly pyruvated galactan exopolysaccharide. Carbohyd. Res., 338, 1851-1859

Viana, A.G., Noseda, M.D., Duarte, M.E.R., Cerezo, A.S. (2004),. Alkali modification of carrageenans. Part V. The iota-nu hybrid carrageenan from Eucheuma denticulatum and its cyclization to iotacarrageenan. Carbohyd. Polym., 58, 455-460

Villanueva, R., Montaño, N. (1999), Highly methylated agar from Gracilaria edulis (Gracilariales, Rhodophyta). J. Appl. Phycol., 11, 225-227

Vincken, J.P., Schols, H.A., Oomen, R.J., McCann, M.C., Ulvskov, P., Voragen, A.G., Visser, R.G. (2003), If homogalacturonan were a side chain of rhamnogalacturonan I. Implication for cell wall architecture. Plant Physiol., 132(4), 1781-1789

Vinogradov, E., Wasser, S.P. (2005), The structure of a polysaccharide isolated from Inonotus levis P. Karst. mushroom (Heterobasidiomycetes). Carbohyd. Res., 340, 2821-2825

Vogl, H., Paper, D.H., Franz, G. (2000), Preparation of a sulfated linear $(1,4)-\beta$-D-galactan with variable degrees of sulfation. Carbohyd. Polym., 41, 185-190.

Witvrouw, M., De Clercq, E. (1997), Sulfated polysaccharides extracted from sea algae as potential antiviral drugs. General Pharmaceuticals, 29, 497511

Wood, P.J., Siddiqui, I.R. (1972), Isolation and structural studies of a water-soluble galactan from potato (Solanum tuberosum) tubers. Carbohyd. Res., 22, 212-220
Yu, K.W., Kiyohara, H., Matsumoto, T., Yang, H.C., Yamada, H. (2001), Structural characterization of intestinal immune system modulating new arabino-3, 6-galactan from rhizomes of Atractylodes lancea DC. Carbohyd. Polym., 46, 147-156

Yu, G., LeBrun, L., Gunay, N.S., Hoppensteadt, D., Walenga, J.M., Fareed, J., Linhardt, R.J. (2000), Heparinase I acts on a synthetic heparin pentasaccharide corresponding to the antithrombin III binding site, Thromb. Res., 100, 549-556

Yuan, H., Song, J., Li, X., Li, N., Dai, J. (2006), Immunomodulation and antitumor activity of kappacarrageenan oligosaccharides. Cancer Lett., 243(2), 228-234

Zemke-White, W.L., Ohno, M. (1999), World seaweed utilisation: An end-of-century summary. J Appl. Phycol., 11, 369-376

Zhang, Y., Kiyohara, H., Sakurai, M., Yamada, H. (1996), Complement activating galactan chains in a pectic arabinogalactan (AGIIb-1) from the roots of Angelica acutiloba Kitagawa. Carbohyd. Polym., 31, 149-156

Zhou, G., Sun, Y.P., Xin, H., Zhang, Y., Li, Z., Xu, Z. (2004), In vivo antitumor and immunomodulation activities of different molecular weight lambdacarrageenans from Chondrus ocellatus. Pharmacol. Res., 50, 47-53

Zibetti, R.G.M., Noseda, M.D., Cerezo, A.S., Duarte, M.E.R. (2005), The system of galactans from Cryptonemia crenulata (Halymeniaceae, Halymeniales) and the structure of two major fractions. Kinetic studies on the alkaline cyclization of the unusual diad G2S-D(L)6S. Carbohyd. Res. 340, 711-722 